\title{
Norepinephrine-induced Inositol 1,4,5-Trisphosphate Formation in Atrial Myocytes is Regulated by Extracellular Calcium, Protein Kinase C, and Calmodulin
}

\author{
Akira KudOH, ${ }^{1} \mathrm{MD}$, Emiko KudOH, ${ }^{2} \mathrm{MD}$, Hiroshi KaTAGAI, ${ }^{1} \mathrm{MD}$ \\ and Tomoko TAKAZAWA, ${ }^{1} \mathrm{MD}$
}

\begin{abstract}
SUMMARY
We investigated whether alteration of extracellular and intracellular $\mathrm{Ca}^{2+}$ concentrations, protein kinase $\mathrm{C}$, and calmodulin modulate norepinephrine(NE)-induced inositol 1,4,5-trisphosphate $\left(\mathrm{IP}_{3}\right)$ formation in neonatal rat atrial myocytes. NE-induced $\mathrm{IP}_{3}$ production in atrial myocytes was stimulated by elevation of extracellular $\mathrm{Ca}^{2+}$ in a dosedependent manner. However, TMB-8 (an intracellular calcium antagonist) and A23187 (an intracellular calcium agonist) did not significantly affect $\mathrm{NE}$-induced $\mathrm{IP}_{3}$ production. PMA (a protein kinase $\mathrm{C}$ agonist) significantly decreased and staurosporine (a protein kinase $\mathrm{C}$ antagonist) significantly stimulated NE-induced $\mathrm{IP}_{3}$ production. W7 (a calmodulin antagonist) significantly increased the $\mathrm{NE}$-induced $\mathrm{IP}_{3}$. In conclusion, elevation of extracellular $\mathrm{Ca}^{2+}$ concentrations affects $\mathrm{NE}$-induced $\mathrm{IP}_{3}$ formation in atrial myocytes. Protein kinase $\mathrm{C}$ and calmodulin may control the $\mathrm{IP}_{3}$ response to $\mathrm{NE}$ by a negative feedback mechanism. (Jpn Heart J 2003; 44: 547-556)
\end{abstract}

Key words: Atrial myocytes, $\mathrm{IP}_{3}$, Calcium, Protein kinase $\mathrm{C}$, Calmodulin, Atrial natriuretic peptide

INOSITOL 1,4,5-trisphosphate ( $\left.\mathrm{IP}_{3}\right)$ plays an important role in excitation and contraction in atrial myocardium. In atrial cells, $\mathrm{IP}_{3}$ is associated with secretion of atrial natriuretic peptide (ANP). ${ }^{1,2)}$ The stimulation of $\alpha$-adrenergic receptors with norepinephrine (NE) increases ANP secretion. ${ }^{2)}$ The signal transduction of $\mathrm{NE}$ occurs through activation of phospholipase C (PLC), which leads to release of $\mathrm{IP}_{3}$. On the other hand, release of $\mathrm{IP}_{3}$ by NE in atrial cells is also associated with the development of arrhythmias. ${ }^{3)}$ Thus, NE-stimulated $\mathrm{IP}_{3}$ plays an important role in atrial cells, however, intracellular regulation of NE-stimulated $\mathrm{IP}_{3}$ formation in atrial myocytes remains unclear.

From ${ }^{1}$ Department of Anesthesiology, Hirosaki National Hospital, ${ }^{2}$ Department of Pediatrics, Hirosaki National Hospital, Aomori, Japan.

Address for correspondence: Akira Kudoh, MD, Department of Anesthesiology, Hirosaki National Hospital, 1 Tominocho, Hirosaki, 036-8545, Aomori, Japan

Received for publication September 6, 2002.

Revised and accepted November 28, 2002. 
NE activates PLC and stimulates the rapid formation of $\mathrm{IP}_{3}$ and diacylglycerol (DAG). $\mathrm{IP}_{3}$ stimulates the release of $\mathrm{Ca}^{2+}$ from sarcoplasmic reticulum. The intracellular calcium binds to calmodulin. The calcium-calmodulin complex activates $\mathrm{Ca}^{2+} / \mathrm{CaM}$-dependent protein kinase and contributes to phosphorylation of myosin light chain. DAG produces protein kinase $\mathrm{C}$ (PKC), which also plays an important role in phosphorylation of myosin light chain. ${ }^{4)}$ Activation of PKC, increases in extracellular and intracellular $\mathrm{Ca}^{2+}$, and calmodulin each enhances ANP secretion by $\alpha 1$-adrenoceptor stimulation. ${ }^{1)}$ Increases in intracellular and extracellular $\mathrm{Ca}^{2+}$, PKC, and calmodulin have a significant role in arrhythmias. ${ }^{5}$ In this study, we investigated the effect of alteration of extracellular and intracellular $\mathrm{Ca}^{2+}, \mathrm{PKC}$, and calmodulin on $\mathrm{NE}$-induced $\mathrm{IP}_{3}$ formation in neonatal rat atrial myocytes.

\section{METHODS}

Isolation of cardiomyocytes from neonatal rat heart: The research was conducted according to the Helsinki Declaration and approved by our animal use committee. Three-day-old neonatal rats were anesthetized with sevoflurane and killed by cervical dislocation. Myocytes were isolated using an aseptic technique. The hearts were rapidly removed and placed in ice-cold $\mathrm{Ca}^{2+}$ - and $\mathrm{Mg}^{2+}$-free PBS containing $40 \mathrm{U} \mathrm{mL}^{-1}$ sodium heparin, $4 \mathrm{mM}$ glucose, and $25 \mathrm{mM}$ HEPES. The hearts were washed with 4 liters of PBS. The atria and ventricles were divided and kept in icecold MEM and PBS, respectively. The atria were minced with scissors into 1 to 3 $\mathrm{mm}^{3}$ fragments, which were then washed with PBS by gently stirring in a $37^{\circ} \mathrm{C}$ water-jacketed Erlenmeyer flask for 10 minutes. The tissue was then enzymatically digested five times for 10 minutes each with $10 \mathrm{~mL}$ PBS containing $0.1 \%$ trypsin, $0.1 \%$ collagenase (type 5), $15 \mathrm{~g} \mathrm{~mL}^{-1}$ deoxyribonuclease 1 , and $1 \%$ chicken serum. The liberated cells were collected by centrifugation at $200 \times \mathrm{g}$ and resuspended in PBS. The pooled and washed cells were plated in T-75 cell culture flasks in minimal essential medium (containing Hank's salts, L-glutamine, 5\% chicken serum, $3 \mathrm{mM}$ pyruvic acid, MEN vitamins, $1 \mathrm{~g} \mathrm{~mL}^{-1}$ insulin, $1 \mathrm{~g} \mathrm{~mL}^{-1}$ transferrin, $10 \mathrm{ng} \mathrm{mL}^{-1}$ selenium, and $50 \mathrm{~g} \mathrm{~mL}^{-1}$ gentamicin). The nonadherent cells were harvested after incubation at $37^{\circ} \mathrm{C}$ for 60 minutes in a humidified incubator with $5 \% \mathrm{CO}_{2}$ in air. The cells were counted and resuspended in minimal essential medium containing $0.1 \mathrm{mM}$ 5-bromo-2'deoxyuridine to inhibit cell division and thereby control nonmyocyte cell growth. Fibroblasts were separated from cardiomyocytes. The suspension was then transferred to $0.1 \%$ gelatincoated $25 \mathrm{~cm}^{2}$ flasks for measurement of $\mathrm{IP}_{3}$. The culture medium was changed after 48 hours to the above media and finally to serum-free medium 24 hours before the cells were studied. After four days, the cells were used at confluence 
for this study to provide stable data. A highly enriched population of myocardiocytes was identified by light microscope examination and the cultures could be maintained for at least 14 days with little change in overall cell morphology.

$\mathbf{I P}_{\mathbf{3}}$ measurement: Twenty-four hours before the experiments, the culture medium was changed to calcium free minimal essential medium. After NE was added for 20 seconds, the reaction was stopped by addition of $5 \mathrm{~mL}$ ice-cold $1 \mathrm{M}$ trichloroacetic acid (TCA) for each $1 \mathrm{mg}$ of cells. The acid extract was homogenized and centrifuged at $0-4^{\circ} \mathrm{C}$ for 10 minutes at $1000 \times \mathrm{g}$. TCA was removed from the extracts by adding $2 \mathrm{~mL}$ of a mixture of 3 vol of 1,1,2-trichloro-1,2,2trifluoroethane plus $1 \mathrm{vol}$ of trioctylamine for each $\mathrm{mL}$ of TCA extract. $\mathrm{IP}_{3}$ content in the aqueous top layer was determined by means of a radioreceptor assay kit (NEN Research Products, Boston, USA).

The cultures were incubated at extracellular $\mathrm{Ca}^{2+}$ concentrations of $0,0.25$, $0.5,1$, and $5 \mathrm{mM}$ for 60 minutes before adding NE. Cells were treated with phorbol 12 myristate 13 acetate (PMA)(a PKC agonist) for 10 minutes, and staurosporine (a PKC antagonist), 8-(N,N diethylamino)octyl-3,4,5-trimethoxybenzoate (TMB-8) (an intracellular calcium antagonist), A23187 (an intracellular calcium agonist), and N-(6-aminohexyl)-5-chloro-naphthalenesulphonamide (W7) (a calmodulin antagonist) for 30 minutes before exposure to NE. The PMA, staurosporine, and $\mathrm{W} 7$ experiments were conducted in the presence of $0.5 \mu \mathrm{M}$ of extracellular calcium.

Protein measurements: Protein was determined by the method of Bradford using bovine serum albumin as standard. ${ }^{6}$ )

Measurement of intracellular calcium mobilization: To evaluate whether TMB-8 and A23187 cause mobilization of intracellular calcium, we used the fluorescent calcium indicator chlortetracycline. Cell suspensions were incubated with $10 \mu \mathrm{M}$ chlortetracycline for two hours at $25^{\circ} \mathrm{C}$. Four samples were withdrawn one minute after the addition of NE. TMB- 8 or A23187 was added 15 minutes before the addition of NE. The samples were placed into plastic conical centrifuge tubes and centrifuged at $7000 \times \mathrm{g}$ for one minute. Immediately after centrifugation, the supernatant was aspirated, leaving the undisturbed pellets in the tube tips. The tube tips were removed with a hot surgical blade and placed in acrylic holders for fluorescence determination with a photon-counting microspectrofluorometer.

Protein kinase C assay: Cardiomyocytes were exposed to NE, PMA, or staurosporine for the indicated times. Cells were then homogenized in buffer containing $20 \mathrm{mM}$ Hepes, $5 \mathrm{mM}$ EGTA, $0.25 \mathrm{mM}$ sucrose, $5 \mathrm{mM}$ DTT, $1 \mathrm{~g} \mathrm{~L}^{-1} \mathrm{BSA}$, and 50 $\mu \mathrm{g} \mathrm{mL} \mathrm{mL}^{-1}$ leupeptin by sonication (five times for 10 seconds) followed by $9 \times 4$ strokes in a glass potter homogenizer. The whole homogenate was considered as the cytosolic fraction. The pellet was solubilized in homogenizing buffer containing $0.4 \%$ Triton X-100 and centrifuged at $10,000 \times \mathrm{g}$ for 10 minutes. Both frac- 
tions were then applied to DEAE-cellulose columns, which were washed with 2.5 $\mathrm{mL}$ of a buffer containing $20 \mathrm{mM}$ Tris- $\mathrm{HCl}$ (pH 7.4), 2 mM EDTA, 5 mM EGTA, and $2 \mathrm{mM}$ PMSF. PKC was eluted with the same buffer containing $100 \mathrm{mM}$ $\mathrm{NaCl}$. PKC activity was then determined by measuring the $\mathrm{Ca}^{2+}$ and phospholipid-dependent transfer of ${ }^{32} \mathrm{P}$ from $\left[{ }^{32} \mathrm{P}\right] \mathrm{ATP}$ to histone III-S. One hundred $\mu \mathrm{L}$ of the eluate was added to $150 \mu \mathrm{L}$ of a solution containing $20 \mathrm{mM}$ Tris- $\mathrm{HCl}$ (pH 7.5), $10 \mathrm{mM}$ magnesium acetate, $25 \mu \mathrm{g}$ histone III-S either in the absence or presence of $0.75 \mathrm{mM} \mathrm{CaCl}_{2}, 12 \mu \mathrm{g}$ of phosphatidylserine, and $1.6 \mu \mathrm{g}$ of $1,2-$ diolein. The reaction was started by addition of $50 \mu \mathrm{M}$ ATP containing $5 \mu \mathrm{Ci}$ of $\left[{ }^{32} \mathrm{P}\right]$ ATP per assay and conducted for 30 minutes at room temperature. Histone was then precipitated by the addition of ice-cold $25 \%$ trichloroacetic acid and separated by filtration on $0.45 \mu \mathrm{m}$ nitrocellulose filters. Filters were then counted by liquid scintillation. Translocation of PKC was determined by measuring the ratio of membrane associated activity/total activity (total activity is cytosolic activity plus particulate activity).

Measurement of ANP secretion: Twenty-four hours before the experiments, the culture medium was changed to serum-free minimal essential medium. Cardiomyocytes were exposed to $1 \mu \mathrm{M} \mathrm{NE}, 0.25,0.5,1$, and $5 \mu \mathrm{M}$ extracellular calcium, $10 \mu \mathrm{M}$ A23187, and $10 \mathrm{nM}$ PMA or $1 \mu \mathrm{M}$ W7 for the indicated times at $37^{\circ} \mathrm{C}$ in $5 \% \mathrm{CO}_{2}$, after which the entire supernatant was collected. ANP was measured by radioimmunoassay (RIA)(Eiken, Tokyo). The mean intra-assay and interassay $\mathrm{CV}$ were $10.5 \%$ and $12.5 \%$, respectively.

Solutions and drugs: Norepinephrine, ANP, the stable analog of TMB-8, A23187, PMA, staurosporine, and W7 were purchased from Sigma Chemical Co. (St Louis, USA). A radioreceptor assay kit for measurement of $\mathrm{IP}_{3}$ was purchased from NEN Research Products (Boston, USA). PMA and staurosporine were dissolved in $0.1 \%$ dimethyl sulfoxide.

Statistical analysis: The data are expressed as the mean \pm standard error of the mean. Each experiment was carried out in duplicate. Every experiment was repeated six times with different cell preparations unless otherwise specified. Statistical comparisons were made using ANOVA for repeated measures and the Student-Newman-Keuls multiple comparison test. Differences in mean values were considered significant at $P<0.05$.

\section{RESULTS}

Exposure to $100 \mathrm{nM}, 1,10$, and $100 \mu \mathrm{M}$ of $\mathrm{NE}$ increased $\mathrm{IP}_{3}$ production from a basal level of $106.5 \pm 9.1$ to $272.2 \pm 23.1,344.7 \pm 19.4,416.0 \pm 24.8$, and $474.0 \pm 34.8$ pmol mg protein ${ }^{-1}$, respectively $(P<0.001)$. 
Figure 1 shows the effect on NE-induced $\mathrm{IP}_{3}$ production under various concentrations of extracellular calcium. After exposure to $0.25,0.5,1$, and $5 \mathrm{mM}$ $\mathrm{Ca}^{2+}, \mathrm{IP}_{3}$ production increased significantly from $275.2 \pm 15.3 \mathrm{pmol} \mathrm{mg}$ protein $^{-1}$ in the absence of $\mathrm{Ca}^{2+}$ to $305.3 \pm 22.0,344.7 \pm 19.4,431.7 \pm 21.4$, and $506.3 \pm$ 22.6 pmol mg protein ${ }^{-1}$, respectively.

We investigated the effects of TMB-8 (an intracellular $\mathrm{Ca}^{2+}$ antagonist) and $\mathrm{A} 23187$ (an intracellular $\mathrm{Ca}^{2+}$ agonist) on $\mathrm{NE}(1 \mu \mathrm{M})$-induced $\mathrm{IP}_{3}$. One and 10 $\mu \mathrm{M}$ TMB-8 and A23187 did not significantly affect NE-induced $\mathrm{IP}_{3}$ production. NE $(1 \mu \mathrm{M})$ significantly stimulated mobilization of intracellular $\mathrm{Ca}^{2+}$ by $78 \%$. Ten $\mu$ M TMB-8 significantly blocked mobilization of intracellular $\mathrm{Ca}^{2+}$ by $67 \%$ and $10 \mu \mathrm{M}$ A23187 significantly stimulated mobilization of intracellular $\mathrm{Ca}^{2+}$ by $92 \%(P<0.001)$.

To study the effect of $\mathrm{PKC}$ on NE-induced $\mathrm{IP}_{3}$ production, we studied the effects of PMA (a PKC agonist) and staurosporine (a PKC antagonist) on NEinduced $\mathrm{IP}_{3}$ production. PMA alone or staurosporine alone had no effect on $\mathrm{IP}_{3}$ production. The ratio of membrane activity/cytosolic activity plus membrane activity changed from $0.38 \pm 0.04$ of control to $0.77 \pm 0.09$ after $10 \mathrm{nM}$ PMA

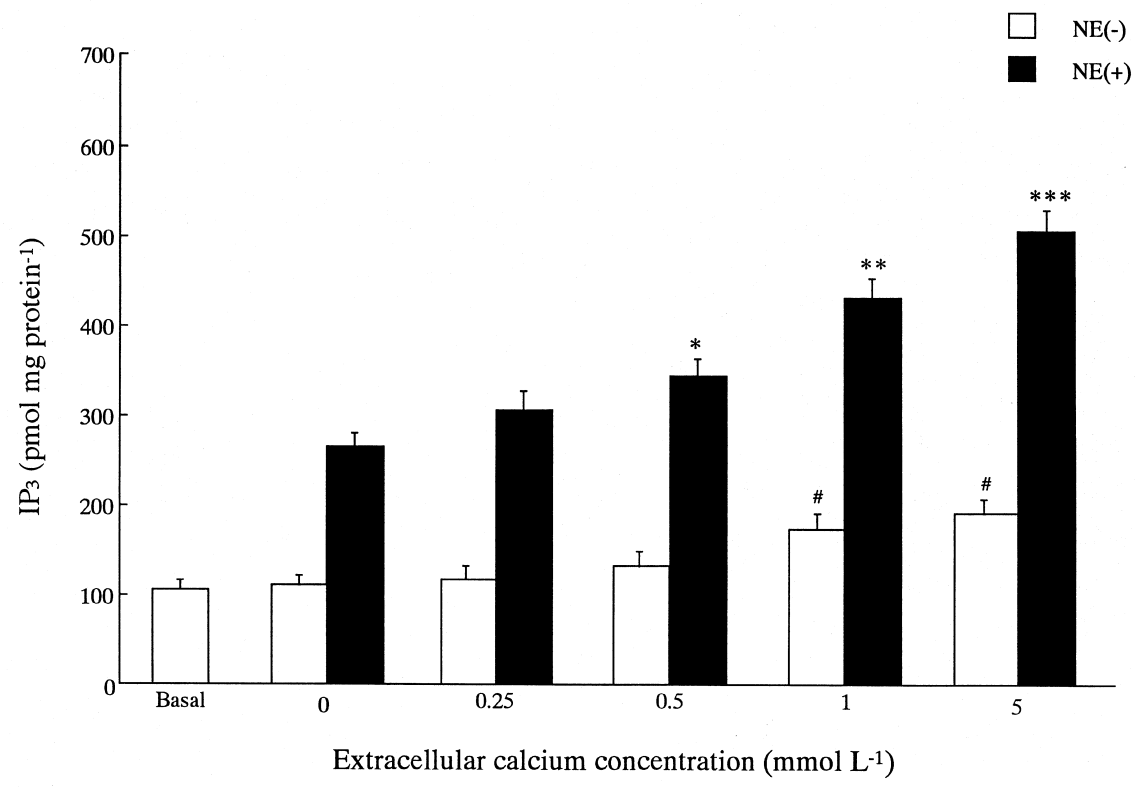

Figure 1. Effect of extracellular calcium on NE-induced $\mathrm{IP}_{3}$ production. Cardiomyocytes were incubated for $60 \mathrm{~min}-$ utes at $37^{\circ} \mathrm{C}$ in the presence of extracellular calcium $(0,0.25,0.5,1$ and $5 \mathrm{mM}) . \mathrm{IP}_{3}$ production was measured after $\mathrm{NE}$ $(1 \mu \mathrm{M})$ stimulation for 20 seconds as described in the Methods. Data are mean \pm SEM. $n=6 . *: P<0.05, * *: P<0.01$, ***: $P<0.001$ vs NE-induced $\mathrm{IP}_{3}$ production in absence of extracellular calcium. $\#: P<0.05$, vs basal. 
administration, $0.27 \pm 0.02$ after $10 \mathrm{nM}$ staurosporine administration, and $0.54 \pm$ 0.08 after $1 \mu \mathrm{M} \mathrm{NE}$ administration. One and $10 \mathrm{nM}$ PMA significantly decreased NE-induced $\mathrm{IP}_{3}$ production from $344.7 \pm 19.4$ to $267.3 \pm 19.4$ and $221.8 \pm 14.8$ pmol mg protein ${ }^{-1}$. One and $10 \mathrm{nM}$ staurosporine significantly stimulated $\mathrm{IP}_{3}$ production from $344.7 \pm 19.4$ to $411.3 \pm 28.3$ and $482.5 \pm 25.7 \mathrm{pmol} \mathrm{mg} \mathrm{protein}^{-1}$ (Figure 2).

We studied the effect of W7, a calmodulin antagonist, on NE-induced $\mathrm{IP}_{3}$ production. One $\mu \mathrm{M} \mathrm{W7}$ alone had no effect on $\mathrm{IP}_{3}$ production. One hundred $\mathrm{nM}$ and $1 \mu \mathrm{M} \mathrm{W} 7$ significantly increased NE-induced $\mathrm{IP}_{3}$ from $344.7 \pm 13.0$ to 410.3 $\pm 19.3(P<0.05)$ and $523.5 \pm 34.7(P<0.01)$ pmol mg protein ${ }^{-1}$.

ANP secretion from atrial cells increased from $0.63 \pm 0.6 \mathrm{pmol} \mathrm{mL}^{-1}$ of control to $5.22 \pm 0.75 \mathrm{pmol} \mathrm{mL}^{-1}$ after administration of $1 \mu \mathrm{M} \mathrm{NE}, 2.58 \pm 0.31 \mathrm{pmol}$ $\mathrm{mL}^{-1}$ after administration of $0.5 \mu \mathrm{M}$ extracellular calcium, $2.01 \pm 0.64 \mathrm{pmol} \mathrm{mL}-$ 1 after administration of $10 \mu \mathrm{M} \mathrm{A} 23187,3.60 \pm 0.38 \mathrm{pmol} \mathrm{mL}^{-1}$ after administration of $10 \mathrm{nM}$ PMA or $2.37 \pm 0.39 \mathrm{pmol} \mathrm{mL}^{-1}$ after administration of $1 \mu \mathrm{M} \mathrm{W}$.

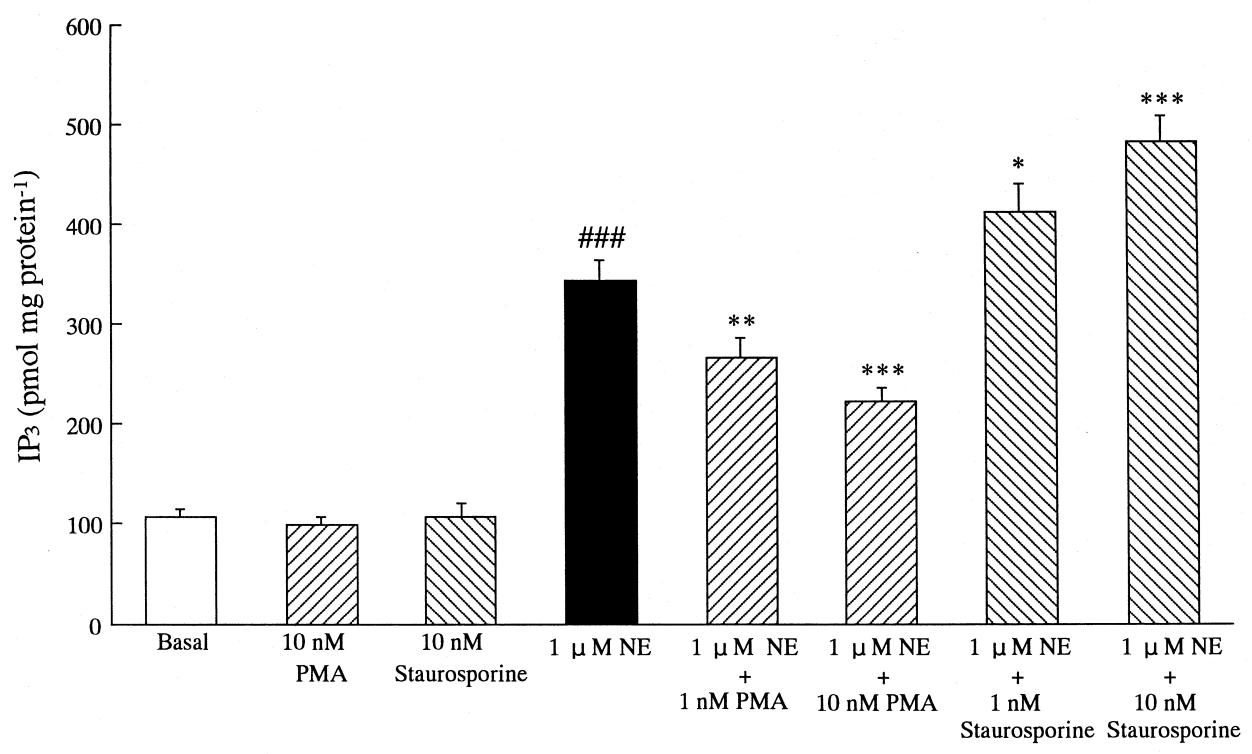

Figure 2. Effect of phorbol 12 myristate 13 acetate (PMA)(a PKC agonist) and staurosporine (a PKC antagonist) on NEinduced $\mathrm{IP}_{3}$ production. The cultures were incubated at $37^{\circ} \mathrm{C}$ in the presence of 1 and $10 \mathrm{nM}$ PMA for 30 minutes and 1 and 10 $\mathrm{nM}$ staurosporin for 30 minutes. $\mathrm{IP}_{3}$ production was measured after $\mathrm{NE}(1 \mu \mathrm{M})$ stimulation for 20 seconds as described in the Methods. The concentration of extracellular calcium in the culture was $0.5 \mu \mathrm{M}$. Data are mean \pm SEM. $n=6$. *: $P<0.05, * *: P$ $<0.01$, ***: $P<0.001$, vs NE-induced $\mathrm{IP}_{3}$ production. \#\#\#: $P<0.001$, vs Basal. 


\section{DISCUSSION}

We found that NE-induced $\mathrm{IP}_{3}$ production in atrial myocytes was stimulated by extracellular $\mathrm{Ca}^{2+}$ in a dose-dependent manner. G-protein activated by extracellular $\mathrm{Ca}^{2+}$ stimulates PLC to activate mobilization of intracellular $\mathrm{Ca}^{2+}$ stores and stimulate $\mathrm{Ca}^{2+}$ entry across the plasma membrane depending on phosphoinositide turnover. ${ }^{7)}$ Extracellular $\mathrm{Ca}^{2+}$ is reported to activate G-protein via calcium ion sensing receptors. ${ }^{8)} \mathrm{NE}$ increased the intracellular $\mathrm{Ca}^{2+}$ concentration. The increase appears to be due to both activation of mobilization of intracellular $\mathrm{Ca}^{2+}$ stores and stimulation of $\mathrm{Ca}^{2+}$ entry across the plasma membrane. Thus, $\mathrm{IP}_{3}$ production stimulated by extracellular $\mathrm{Ca}^{2+}$ appears to be associated with calcium ion sensing receptors. TMB-8 (an intracellular calcium antagonist) and A23187 (an intracellular calcium agonist) could not significantly affect the NE-induced $\mathrm{IP}_{3}$ production. TMB-8 inhibits $\mathrm{Ca}^{2+}$ influx from plasma membrane and $\mathrm{IP}_{3}$-induced $\mathrm{Ca}^{2+}$ release from sarcoplasmic reticulum (SR). ${ }^{9)} \mathrm{A} 23187$ selectively acts on voltage-dependent $\mathrm{Ca}^{2+}$ channels, resulting in elevation of the intracellular calcium concentration. $\mathrm{NE}$-induced $\mathrm{IP}_{3}$ production is regulated by extracellular $\mathrm{Ca}^{2+}$, but not by intracellular $\mathrm{Ca}^{2+}$ in atrial myocytes. These results support the finding that ANP released by elevation of extracellular $\mathrm{Ca}^{2+}$ is associated with elevation of NE-induced $\mathrm{IP}_{3}$ production. ${ }^{1)}$ However, ANP release by elevation of intracellular $\mathrm{Ca}^{2+}$ appears to involve a different pathway from that of NE-induced $\mathrm{IP}_{3}$ production.

We investigated whether PMA (a PKC agonist) or staurosporine (a PKC antagonist) affect $\mathrm{NE}$-induced $\mathrm{IP}_{3}$ formation. $\mathrm{NE}$ activated $\mathrm{PKC}$ and the treatment with PMA inhibited NE-induced $\mathrm{IP}_{3}$ formation and the treatment with staurosporine stimulated $\mathrm{NE}$-induced $\mathrm{IP}_{3}$ formation, indicating that there is feedback regulation of $\mathrm{PKC}$ to $\mathrm{IP}_{3}$. Langendorff perfusion in guinea pig hearts with PMA causes an impairment of contraction of the left ventricle and the down-regulation by activation of PKC may be associated with a decrease in inositol phosphates. ${ }^{10)}$ Barr and Watson reported that a PKC inhibitor potentiated agonist-stimulated accumulation of inositol phosphates in astrocytoma cells. ${ }^{11)}$ They suggested that the inhibitory feedback by PKC may mediate phosphorylation of PLC. Thus, the inhibitory effect of PKC on NE-induced $\mathrm{IP}_{3}$ formation appears to be associated with both receptor desensitization and down-regulation in atrial myocytes.

The $\mathrm{IP}_{3}$-induced $\mathrm{Ca}^{2+}$ release requires calmodulin-dependent $\mathrm{IP}_{3}$ receptor phosphorylation. ${ }^{12)} \mathrm{W} 7$ interferes with the binding between the calmodulin receptor and $\mathrm{Ca}^{2+}$-calmodulin complex in cardiomyocytes. ${ }^{13)} \mathrm{We}$ found that $\mathrm{W} 7$ has a positive effect on NE-induced $\mathrm{IP}_{3}$ formation. Wolf, et al reported that $\mathrm{W} 7$ caused $\mathrm{Ca}^{2+}$ release from $\mathrm{SR}$ and potentiated $\mathrm{IP}_{3}$-induced $\mathrm{Ca}^{2+}$ mobilization. ${ }^{14)}$ These results indicate that $\mathrm{W} 7$ causes $\mathrm{Ca}^{2+}$ release from SR through elevation of $\mathrm{IP}_{3}$. $\mathrm{IP}_{3}$ is metabolized by a $\mathrm{IP}_{3}$-3-kinase to $\mathrm{IP}_{4}$. The $\mathrm{IP}_{3}$-3-kinase is activated in 
a calmodulin dependent manner. ${ }^{15)}$ This phenomenon autocatalytically enhances the $\mathrm{Ca}^{2+}$ signal, as $\mathrm{IP}_{4}$ promotes the $\mathrm{Ca}^{2+}$-mobilizing function of $\mathrm{IP}_{3}$ and inhibits $\mathrm{IP}_{3}$ dephosphorylation. Thus, it is possible that $\mathrm{IP}_{3}$ formation stimulated by the calmodulin antagonist is mediated partly by a negative feedback mechanism that controls the $\mathrm{IP}_{3}$ response to NE.

Signaling pathway NE-induced $\mathrm{IP}_{3}$ formation in atrial cells is shown in Figure 3. NE activates PLC, resulting in the rapid formation of $\mathrm{IP}_{3}$ and DAG. $\mathrm{IP}_{3}$ stimulates the release of $\mathrm{Ca}^{2+}$ from sarcoplasmic reticulum. The intracellular calcium binds to calmodulin. The calcium-calmodulin complex activates $\mathrm{Ca}^{2+} / \mathrm{CaM}$ dependent protein kinase and contributes to phosphorylation of myosin light chain. DAG produces PKC, which also plays an important role in phosphorylation of myosin light chain. Extracellular $\mathrm{Ca}^{2+}$ increases NE-induced $\mathrm{IP}_{3}$ formation through activation of G-protein via calcium ion sensing receptors. PMA significantly decreased and staurosporine significantly stimulated NE-induced $\mathrm{IP}_{3}$ production. W7 (a calmodulin antagonist) significantly increased the NE-induced $\mathrm{IP}_{3}$.

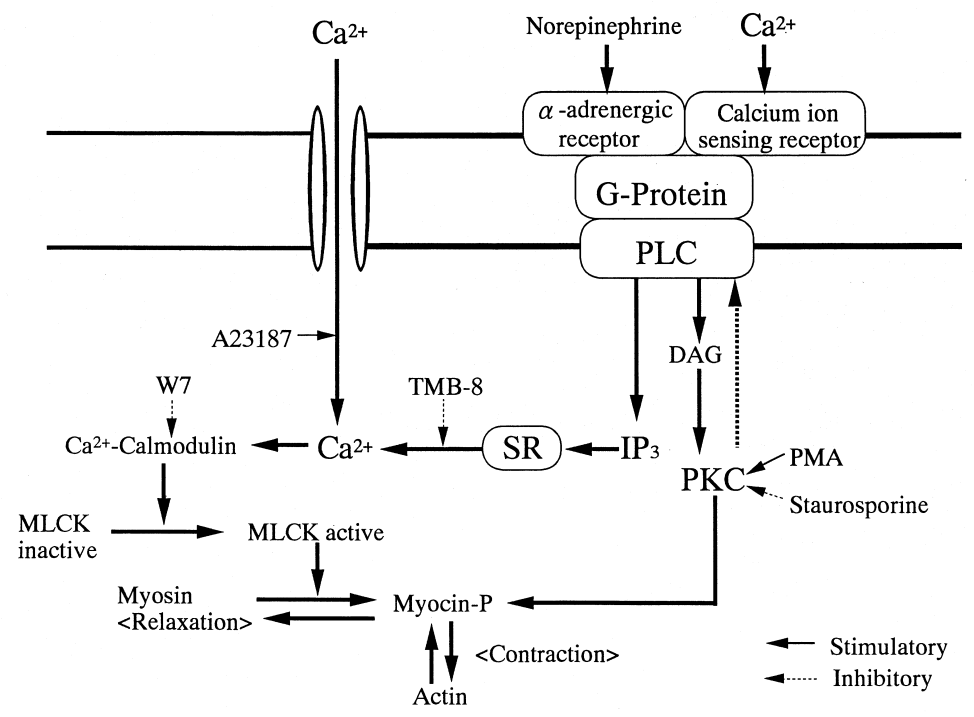

Figure 3. NE activates PLC, resulting in the rapid formation of $\mathrm{IP}_{3}$ and DAG. $\mathrm{IP}_{3}$ stimulates the release of $\mathrm{Ca}^{2+}$ from sarcoplasmic reticulum. The intracellular calcium binds to calmodulin. The calcium-calmodulin complex activates $\mathrm{Ca}^{2+} / \mathrm{CaM}$-dependent protein kinase and contributes to phosphorylation of myosin light chain. DAG produces PKC, which also plays an important role in phosphorylation of myosin light chains. Extracellular $\mathrm{Ca}^{2+}$ increases $\mathrm{NE}$-induced $\mathrm{IP}_{3}$ formation through activation of G-protein via calcium ion sensing receptors. PMA (a PKC agonist) significantly decreased and staurosporine (a PKC antagonist) significantly stimulated NE-induced $\mathrm{IP}_{3}$ production. W7 (a calmodulin antagonist) significantly increased the NE-induced $\mathrm{IP}_{3}$. 
Neonatal myocardium is more sensitive to extracellular calcium concentrations than is adult myocardium. This is related to the poorly developed sarcoplasmic reticulum of neonatal myocardium. ${ }^{16)}$ It is unclear whether the intracellular changes associated with maturation of the atrial myocytes affect NE-induced $\mathrm{IP}_{3}$ formation. PMA, staurosporine, TMB-8, and W7 have been used for many years as pharmacologic tools. PMA and staurosporine are known as a PKC agonist and antagonist, respectively. We used 1 and $10 \mathrm{nM}$ PMA and staurosporine for preventing several actions at high concentrations. TMB-8 inhibits the release of intracellularly stored $\mathrm{Ca}^{2+}{ }^{16)}$ Two $\mu \mathrm{M}$ TMB-8 for 15 minutes significantly decreased the concentration of intracellular calcium in atrial muscle. As high concentrations of TMB-8 have several actions, including depression of protein kinase $\mathrm{C}$ and tyrosine kinase, ${ }^{17)}$ the culture was exposed for 30 minutes at a concentration of $1 \mu \mathrm{M}$ TMB-8 in this study. W-7 has been reported to increase the release from the SR by interfering with the binding between the calmodulin receptor and $\mathrm{Ca}^{2+}$-calmodulin complex, ${ }^{18)}$ but is ineffective as an inhibitor of PKC or protein kinase A. ${ }^{19)}$ Thus, PMA, staurosporine, TMB-8, or W7 at the concentration used in this study appear to be specific.

In conclusion, elevation of extracellular $\mathrm{Ca}^{2+}$ concentrations affects NEinduced $\mathrm{IP}_{3}$ formation in neonatal rat atrial myocytes. $\mathrm{PKC}$ and calmodulin are involved in regulation of the $\mathrm{IP}_{3}$ response to $\mathrm{NE}$.

\section{ACKNOWLEDGMENT}

The authors thank Dr Paul Hollister for his critical review of the paper.

\section{REFERENCES}

1. Ambler SK, Leite MF. Regulation of atrial natriuretic peptide secretion by alpha1-adrenergic receptors: the role of a different second messenger pathway. J Mol Cell Cardiol 1994; 26: 391-402.

2. Brunner F, Mouton R, Opie LH. Defective stretch-induced release of atrial natriuretic peptide from aging hypertensive rat heart: possible role of phosphatidylinositol pathway. J Cardiovasc Pharmacol 1995; 25: 16876.

3. Hayashi $\mathrm{H}$, Miyata $\mathrm{H}$, Terada $\mathrm{H}$, et al. Effects of phospholipase $\mathrm{C}$ on action potentials and intracellular $\mathrm{Ca}^{2+}$ concentration in guinea pig heart. Jpn Circ J 1993; 57: 344-52.

4. Endo T, Naka M, Hidaka H. $\mathrm{Ca}^{2+}$ phospholipid-dependent phosphorylation of smooth muscle myosin. Biochem Biophys Res Comm 1982; 105: 942-8.

5. Brooks WW, Conrad CH, Morgan JP. Reperfusion-induced arrhythmias following ischemia in intact rat heart: role of intracellular calcium. Cardiovas Res 1995; 29: 536-42.

6. Bradford MM. A rapid and sensitive method for the quantitation of microgram quantities of protein utilizing the principle of protein-dye binding. Anal Bioch 1976; 72: 248-54.

7. Van Heughten HAA, De Jonge HW, Bezstarosti K, et al. Calcium and endothelin- 1 and $\alpha 1$-adrenergic stimulated phosphatidylinositol cycle cultured rat cardiomyocytes. J Mol Cell Cardiol 1994; 26: 1081-93.

8. Renard D, Poggioli J. Mediation by GTP $\gamma \mathrm{S}$ and $\mathrm{Ca}^{2+}$ of inositol triphosphate generation in rat heart membranes. J Mol Cell Cardiol 1990; 22: 13-22. 
9. Kojima I, Kojima K, Rasmussen H. Mechanism of inhibitory action of TMB-8[8-(N,N-diethylamino)octyl3,4,5-trimathoxybenzoate] on aldosterone secretion in adrenal glomerulose cells. Biochem J 1985; 232: 87-92.

10. Edes I, Kranias EG. The effect of phorbol esters and diacylglycerol analogues on the basal phosphoinositide turnover in isolated guinea pig hearts. Cardioscience 1990; 1: 265-74.

11. Barr AJ, Watson SP. Protein kinase C mediates delayed inhibitory feedback regulation of human neurokinin type 1 receptor activation of phospholipase C in UC11 astrocytoma cells. Mol Pharmacol 1994; 46: 266-73.

12. Zhang BX, Zhao H, Muallem S. $\mathrm{Ca}^{2+}$-dependent kinase and phosphatase control inositol 1,4,5-trisphosphatemediated $\mathrm{Ca}^{2+}$ release. J Biol Chem 1993; 268: 10997-1001.

13. Toyama J, Sugiura H, Kamiya K, Kodama I, Terasawa M, Hidaka H. Ca ${ }^{2+}$-calmodulin mediated modulation of the electrical coupling of ventricular myocytes isolated from guinea pig heart. J Mol Cell Cardiol 1994; 26: 1007-15.

14. Wolf BA, Colca JR, McDaniel ML. Calmodulin inhibits inositol trisphosphate-induced $\mathrm{Ca}^{2+}$ mobilization from the endoplasmic reticulum. Biochem Biophys Res Commun 1986; 141: 418-25.

15. Shears SB. Metabolism of the inositol phosphates produced upon receptor activation. Biochem J 1989; 260: 313-24.

16. Klitzner T, Friedman WF. A diminished role for the sarcoplasmic reticulum in newborn myocardial contraction: effects of ryanodine. Pediatr Res 1989; 26: 98-101.

17. Nothover BJ. Effects of 8-(N,N-diethylamino)octyl 3,4,5-trimethoxybenzoate (TMB8) on rat atrial muscle. Biochem Pharmacol 1992; 44: 425-32.

18. Toyama J, Sugiura H, Kamiya K, Kodama I, Terasawa M, Hidaka H. Ca ${ }^{2+}$-calmodulin mediated modulation of the electrical coupling of ventricular myocytes isolated from guinea pig heart. J Mol Cell Cardiol 1994; 26: 1007-15.

19. Hidaka H, Inagaki M, Kawamoto S, Sasaki Y. Isoquinolinesulfonamides, novel and potent inhibitors of cyclic nucleotide-dependent protein kinase and protein kinase C. Biochemistry 1984; 23: 5036-41. 